\title{
Dokumenty życia społecznego w badaniach i praktyczne ich wykorzystanie
} osnąca rola i znaczenie dokumentów życia społecznego w bibliologii, kulturoznawstwie i księgarstwie zmusiła świat bibliotekarski do zastanowienia się nad tą materią. W związku z tym z inicjatywy Stowarzyszenia Bibliotekarzy Polskich oraz Dolnośląskiej Biblioteki Publicznej im. Tadeusza Mikulskiego we Wrocławiu [dalej: DBP] w dniach 6-7 października 2016 r. odbyła się ogólnopolska konferencja „Dokumenty życia społecznego w badaniach i praktyczne ich wykorzystanie”. Konferencja została podzielona na pięć sesji tematycznych, zgłębiających tajniki i analizujących rozmaite zagadnienia związane z dokumentami życia społecznego: dokumenty życia społecznego jako źródło badań i wiedzy praktycznej; praktyki gromadzenia i opracowywania dokumentów życia społecznego; dokumenty życia społecznego w małych bibliotekach; przechowywanie, konserwacja, digitalizacja; dokumenty życia społecznego w sieci.

W pierwszej części dr hab. Renata Tańczuk (Instytut Kulturoznawstwa Uniwersytetu Wrocławskiego, dalej: UWr) przedstawiła postać prof. UWr Pawła Banasia, historyka sztuki kolekcjonującego szkło i ceramikę, znaczki, albumy nutowe, papiery luksusowe, zaproszenia, podziękowania, karty pocztowe itd. Wśród kolekcji prof. Banasia znalazły się także efemerydy, np. albuma bolońskie - ilustrowany dziennik nastolatki z Bolonii. Prelegentka podjęła się próby udowodnienia, że druki, przeznaczone powszechnie do natychmiastowego użycia, mogą uzyskać jednocześnie inną funkcjonalność, nadawaną im przez indywidualne cechy jednostki. Obiekty, początkowo przeznaczone do natychmiastowego zaczytania i zniszczenia, zyskują swoje „drugie życie” i w przyszłości mogą stanowić niezwykle cenne źródło badań społecznych i kulturowych. 
Dr hab. Aneta Firlej-Buzon (Instytut Informacji Naukowej i Bibliotekoznawstwa UWr) omówiła kwestię wartości źródłowej dokumentów życia społecznego, ich potencjału informacyjnego dla aktualnych lub prowadzonych w przyszłości badań naukowych. Według polskich bibliologów (m.in. Karola Estreichera, Krzysztofa Migonia) typologia dokumentów życia społecznego jest niemożliwa, jednakże podejmują się oni próby sklasyfikowania tychże materiałów. Historycy, bibliotekarze, bibliografowie rozumieli wartość dokumentów nieksiążkowych jako narodowej kultury, co przejawiało się w kolekcjonowaniu, opisywaniu i dbałości o przechowywanie.

Prof. Małgorzata Korczyńska-Derkacz oraz mgr Katarzyna Jamrozik (Instytut Informacji Naukowej i Bibliotekoznawstwa UWr) podjęły się analizy bardzo interesującego, ale i trudnego zagadnienia, jakim są jednodniówki, będące w obszarze zainteresowań badaczy i naukowców ze względu na miejsce wydania, środowisko wydawnicze czy też tematykę. Analizie poddano zawartość Biblioteki Cyfrowej Polona, która rejestruje ponad 1200 tzw. jednodniówek.

Dokumenty życia społecznego w rozumieniu materiałów bibliotecznych i archiwalnych są również obiektem zainteresowania rynku antykwarycznego. Dżs-y na rynku wtórnym śledzi dr hab. Grzegorz Nieć (Instytut Nauk o Informacji Uniwersytetu Pedagogicznego w Krakowie). W księgarstwie dokumenty życia społecznego traktuje się jako produkty wprowadzone do obiegu chociaż jeden raz. Stosuje się różne podziały dokumentów życia społecznego na rynku pośrednim. Spośród całej gamy druków przez szereg lat wyodrębniły się pocztówki i plakaty. Rosnąca świadomość wśród społeczeństwa o wartości druków życia codziennego doprowadziła do tego, że również antykwariusze prowadzą prace porządkowe i selekcjonują trafiające do nich obiekty.

Druga i trzecia sesja skupiały się na praktykach gromadzenia i metodach opracowywania dokumentów życia społecznego w wiodących bibliotekach w Polsce, jak i w małych bibliotekach wojewódzkich i miejskich. Z przedstawionych prezentacji wynika, iż zarówno Biblioteka Narodowa w Warszawie [dalej: BN], jak i Biblioteka Uniwersytecka w Warszawie [dalej: BUW] oraz DBP posiadają własne zasady gromadzenia dokumentów życia społecznego. Na potrzeby bibliotek opracowana została polityka gromadzenia tychże materiałów, polityka, która uzależniona jest od profilu biblioteki, od jej specyfiki i indywidualnego odbiorcy. 
Ogromna ilość obiektów zaliczanych do dokumentów życia społecznego wymusza selekcję już w pierwszym etapie zakwalifikowania do zbiorów bibliotecznych. Związane jest to także z możliwościami magazynowymi. Biblioteki nie mają możliwości gromadzenia, przechowywania i udostępniania wszystkich dokumentów wpływających do ośrodka.

Problemem jest również sposób opracowywania dokumentów życia społecznego. BN opracowuje zbiory we własnej bazie katalogowej. Podobnie czyni DBP we Wrocławiu. BUW rozpoczęła katalogowanie komputerowe w bazie lokalnej. Po zaimplementowaniu katalogu centralnego NUKAT rozpoczęto prace nad przeniesieniem pewnych grup dokumentów (np. telegramów patriotycznych) właśnie do NUKAT. Jest to proces bardzo skomplikowany i czasochłonny, wymagający ogromnego nakładu pracy z obu stron. Brak jednolitych i spójnych norm, obejmujących całość zagadnienia, czyni proces katalogowania elektronicznego niezwykle trudnym: ustalenie tytułu dokumentu we właściwej formie, wyznaczenie wszelkich możliwych punktów dostępu itp. Wiele z dokumentów typowanych jako dokumenty życia społecznego posiada zarówno cechy druków ulotnych, jak i cechy innych typów dokumentów, np. ikonograficznych. Podejmując próbę skatalogowania tychże obiektów, należy mieć świadomość istnienia formatów dla różnego rodzaju druków gromadzonych w bibliotekach.

Dokumenty życia społecznego rejestrowane są również $\mathrm{w}$ bibliografiach regionalnych, gdzie także napotyka się na trudności związane z doborem materiału i późniejszym jego opracowaniem. Wiedząc, jakie zadania stoją przed bibliografiami regionalnymi oraz czemu służy rejestracja dżs-ów, nie ma wątpliwości, iż jest to jeden ze sposobów ochrony dziedzictwa narodowego.

Drugi dzień konferencji poświęcony był m.in. omówieniu problematyki dokumentów życia społecznego w małych ośrodkach (Legnicka Biblioteka Publiczna, Miejska i Powiatowa Biblioteka Publiczna w Nowym Tomyślu). W latach 70., kiedy to biblioteki wojewódzkie zostały zobowiązane do upowszechniania wiedzy o regionie oraz dokumentowania życia społecznego, w wielu bibliotekach zaczęto tworzyć odrębne oddziały dżs-ów lub ośrodki wiedzy o regionie. Ich zadaniem jest gromadzenie i upowszechnianie aktualnej wiedzy o danym regionie. Biblioteki na różne sposoby radzą sobie z ogromnym materiałem, np. udostępniają prezencyjnie lub tworzą galerie internetowe. 
Ciekawą inicjatywą są archiwa społeczne, które we współpracy z lokalnym środowiskiem/społeczeństwem, dokumentują różnorodne, często wąskie fragmenty danej społeczności, np. historia zawodu pielęgniarstwa. Pomocą takim inicjatywom oddolnym służy Ośrodek KARTA, który od 2012 r. wspiera te archiwa, dając im narzędzia i niezbędną pomoc.

Niezwykle ciekawym zagadnieniem okazała się kwestia digitalizacji dokumentów życia społecznego. Wiele z bibliotek podejmuje próby digitalizacji i udostępniania dżs-ów w formie cyfrowej. Jest to jeden ze sposobów ochrony, dający jednocześnie możliwości pokazania dokumentu zainteresowanemu użytkownikowi. Często forma cyfrowa okazuje się wystarczająca jako materiał badawczy i w pełni satysfakcjonuje użytkownika. Podczas swojego wystąpienia dr hab. Małgorzata Kowalska (Instytut Informacji Naukowej i Bibliologii Uniwersytetu Mikołaja Kopernika w Toruniu) podjęła próbę analizy różnych aspektów związanych z digitalizacją dokumentów życia społecznego: formalny, techniczny, prawny. Mnogość problemów, w tym niekonsekwencje w opracowaniu, prowadzą do niespójnego prezentowania często identycznych danych, a w konsekwencji do obniżenia standardów wyszukiwania i dotarcia do dokumentu czy całej grupy dokumentów.

Bardzo ważnym elementem pracy z dokumentami życia społecznego, które jak wiadomo nigdy nie były wytwarzane z myślą o ich gromadzeniu, przechowywaniu i udostępnianiu, jest ich ochrona i konserwacja, na co zwróciła uwagę Agata Lipińska z BN. Na zabezpieczanie i ochronę dokumentów ulotnych składa się profilaktyka (dobre warunki przechowywania, dezynsekcja, bezpieczne materiały ochronne, masowe odkwaszanie, digitalizacja) oraz konserwacja (zachowawcza, interwencja konserwatorska przy obiektach bardzo zdegradowanych).

Podczas dwudniowej konferencji widoczne było duże zainteresowanie złożoną problematyką obiektów klasyfikowanych jako dokumenty życia społecznego. Różnorodność materii przełożyła się na mnogość tematów, a wszystkie poruszały ważne aspekty „życia” tzw. dokumentów życia społecznego. Z przygotowanych prezentacji wynika, iż dokumenty życia społecznego są również w sferze zainteresowań innych grup zawodowych, nie tylko tych związanych z dziedzictwem kulturowym. Odnosi się wrażenie, że o ile biblioteki poradziły sobie z kwestią wypracowania (w lepszym lub gorszym zakresie) zasad gromadzenia, przechowywania i udostępniania dżs-ów, to niestety w dalszym ciągu 
nie radzą sobie z ich opracowaniem, skatalogowaniem. Owszem podejmowane są co jakiś czas inicjatywy dotykające niewielkiej części materiału, ale wciąż brak spójnych przepisów. Zrozumiałe jest, że przy tak różnorodnym materiale nie ma możliwości stworzenia jednolitego formatu (w dosłownym słowa tego znaczeniu). Osoby zajmujące się opisywaniem dżs-ów muszą korzystać z formatów przeznaczonych dla różnych typów dokumentów i umiejętnie je wykorzystywać podczas katalogowania. Z przedstawionych wystąpień przebija również problem z metodyką pracy, widoczny niemal w każdej bibliotece podejmującej trud gromadzenia, opracowania, przechowywania i udostępniania dokumentów życia społecznego. Rosnąca świadomość społeczeństwa o unikatowości efemerydów prowadzi do wymuszania na pracownikach bibliotek i ośrodków dokumentacji dokładnego ich opracowywania i rozpowszechniania wśród szerokiej publiczności. Obowiązek ten spoczywa nie tylko na dużych ośrodkach akademickich, a może przede wszystkim na wojewódzkich i miejskich bibliotekach publicznych.

Monika Jóźwiak

Biblioteka Uniwersytecka we Wrocławiu

\section{Open Access Week w Toruniu}

DOI: http://dx.doi.org/10.12775/TSB.2017.014

Dokrocznie, od ośmiu lat, ostatnie dni października poświęcone są Mmiędzynarodowemu szerzeniu idei wolnego dostępu do różnego rodzaju informacji. Wydarzenie to odbywa się pod nazwą Open Access Week, czyli Tydzień Wolnej Nauki.

Początkowo ideą open access było umożliwienie darmowego korzystania z przeróżnych źródeł danych związanych ściśle ze światem nauki, by wspomóc jej rozwój. Dzięki Internetowi każdy na świecie miał mieć możliwość, zwłaszcza jeżeli materiały były dostępne w odpowiednim 